\title{
KARIN FISCHER
}

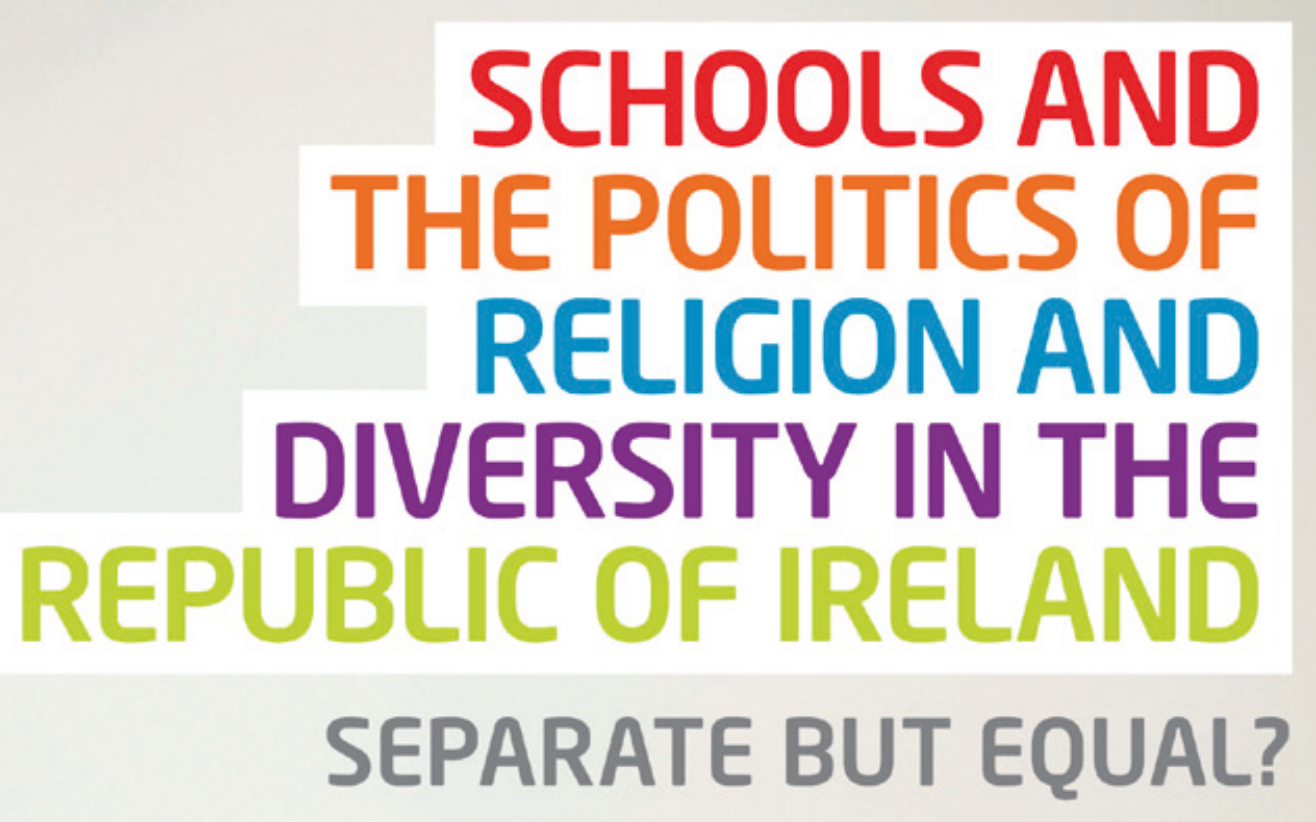


Karin Fischer - 9781526101143 Downloaded from manchesterhive.com at 04/26/2023 02:39:53AM via free access 
Schools and the politics of religion and diversity in the Republic of Ireland

\section{MANCHESTER 1824}

Manchester University Press 
Karin Fischer - 9781526101143 Downloaded from manchesterhive.com at 04/26/2023 02:39:53AM via free access 


\section{Schools and the politics of religion and diversity in the Republic of Ireland}

Separate but equal?

Karin Fischer

Manchester University Press 
Copyright (C) Karin Fischer 2016

The right of Karin Fischer to be identified as the author of this work has been asserted by her in accordance with the Copyright, Designs and Patents Act 1988.

Published by Manchester University Press

Altrincham Street, Manchester M1 7JA

www.manchesteruniversitypress.co.uk

British Library Cataloguing-in-Publication Data

A catalogue record for this book is available from the British Library

Library of Congress Cataloging-in-Publication Data applied for

ISBN 9780719091964 hardback

First published 2016

The publisher has no responsibility for the persistence or accuracy of URLs for any external or third-party internet websites referred to in this book, and does not guarantee that any content on such websites is, or will remain, accurate or appropriate.

Typeset by Out of House Publishing 